SAYI / ISSUE $45 \cdot 2015$

\title{
OSMANLI ARAŞTIRMALARI
}

THE JOURNAL OF OTTOMAN STUDIES

ISAMR

İSTANBUL 29 MAYIS ÜNİVERSITESİ 
could allow the author to get a better grasp of the intricacies of daily encounters between Ottoman officials and European diplomats. Moreover, Ottoman chronicles could have served as a background against which Ghobrial could check the veracity of rumors regarding the deposition of Mehmed IV. Given his emphasis on oral communication, a cross-reading of Ottoman and European sources could have offered new insights and yielded interesting conclusions.

In fine, John-Paul Ghobrial's book is a diligently prepared study that succeeded in incorporating Ottoman Empire into the overtly Eurocentric historiography of early modern news and communication that privileged printed forms of communication over oral and scribal forms.

Emrah Safa Gürkan

Yahya Araz,

\section{Yüzyzldan 19. Yüzyıl Başlarına: Osmanlı Toplumunda Çocuk Olmak,}

İstanbul: Kitap Yayınevi, 2013, 196 s., ISBN 978-605-105-118-5

Çocuk tarihi çalışmaları ülkemizde henüz fazla ilgi görmemiş bir alan olarak araştırmacılarını beklemektedir. Alandaki ilk özgün çalışmalardan biri Yahya Araz'ın, birincil kaynak olarak Şeriyye Sicillerini kullandığı ve İslâm hukukundan beslenerek kaleme aldığı Osmanlı Toplumunda Çocuk Olmak başlıklı araştırmasıdır. Çocukluk yıllarının cazibesinin Batı'da da yeni bir olgu olduğundan bahseden yazar, 20. yüzyılın ikinci yarısında çocukların yetiştirilmesine yönelik kaygıların, okul sistemindeki gelişmelerin ve çocuk emeğinin kullanımına dair düzenlemelerin sebep olduğu tartışmaların, çocukluğun tarihine gösterilen ilgiyle yakından ilişkili olduğu tezlerine bu çalışmasında yanıt aramaktadır.

Yazar, ülkemizde bu alana karşı olan ilgisizliği, "Osmanlı tarihçileri sadece çocuklar değil onlarla ilişkili olan aileler ve toplum hakkında da önemli ipuçları verebilecek bu alanı görmezden geldiler. Osmanlı tarihçiliğinin Türkiye ve dünyadaki gelişimi karşısında, çocukluğun tarihine gösterilen ilginin azlığı, bu alanın üvey evlat muamelesi gördüğ̈ izlenimi uyandırmaktadır” sözleriyle haklı olarak tenkit etmektedir.

Batı'da 50 yıllık geçmişe sahip olan çocukluk tarihi çalışmalarının, Türkiye'de elle tutulur bir geçmişinin olmaması son derece düşündürücüdür. Yazarın ifadesine 
göre, "Türkiye'de çocukluk tarihinin ilgi çekmediği, yapılan çalışmaların da Tanzimat öncesine uzanmakta zorlandıkları bir vakıadır”. Diğer tarih çalışmaları arasında Türkiye'de son derece mütevazi bir yere sahip olan çocukluk çalışmalarının Tanzimat öncesi dönemi neredeyse hiç ele almaması ve bu alanın boş olmasının yarattığı sıkıntılar, Yahya Araz’ı bu çalışmayı yapmaya sevk etmiş bulunmaktadır.

İçeriği, "Osmanlı toplumunda çocukların yaşamına eğilmek" olarak belirlenen çalışmada, bu içeriği desteklemek için dönemin belgelerinin çocuklarla ilgili söyleyebileceği bütün konular, sosyo-ekonomik ve politik bir tahlile tabi tutulmuştur. Öyle ki, daha önceleri ailenin özel alanı olarak görülen düşük ve doğum kontrolü gibi meselelere devletin müdahaleci tavrının nüfus, aile ve çocukla ilgili yeni politikaların ilk habercisi olduğu ve ilk mekteplerin 1824 tarihli bir fermanla zorunlu hale getirilmesinin devletin geleceğini inşa etmek için çocukların yaşamını düzenlemeye başladığı ifade edilmiştir. Ayrıca, tebenni yani evlat edinme konusunun 18. yüzyılın ikinci yarısında niçin ivme kazandığı gibi meseleleri de çalışmanın içinde bulmak mümkündür.

Bütün bu soruların yer aldığı ve cevaplarının bulunmaya çalışıldığı eser doyurucu bilgilerin yer aldığı giriş dışında sosyal, politik ve ekonomik alanlarda çocuğu ele alan üç ana bölümden oluşmaktadır.

Çalışmada Osmanlı'da çocuğun sosyal çevresinin bir tahlilini yapan "Hukuk, toplum ve ailenin bir parçası olarak çocuklar" adlı birinci bölümün en dikkat çeken vurgusunun "aile" olduğu görülmektedir. Bu bölümde, anne-baba ile geçirilen zamanların çocukların mutlu ve huzurlu olması üzerindeki etkisine ve annesi ya da babası ölen çocukların çektikleri sıkıntı ve yaşadıkları talihsiz hayatlara vurgu yapılarak, arşiv kayıtlarına yansıyan çocuk dramlarına yer verilmektedir. Bu çocukların bir kısmı, yaşamın zorluklarıyla çok erken yaşlarda tanışmışlardı. Bugünden farklı olarak görülebilecek ebeveyn çocuk ilişkisi ise, ilişkinin dinsel referanslar üzerine kurulmuş olmasındandır. Modernle klasik aile arasındaki en belirgin fark terbiye anlayışında ortaya çıkmaktadır. Modern ailede artık görmeye alışık olmadığımız, ebeveynlerine hürmet ve ihtiyarladıklarında onları sahiplenme duygusu, cenneti elde edebilmek için "anne babaya öf bile denmemesi” anlayışına dayanmaktadır. Bu anlamda Osmanlı terbiye anlayışı geleneksel referanslarını dinden almaktadır.

Dönemin sosyo-politik tahlillerinin de yapıldığı ikinci bölüm "Bir çocuğu yetiştirmek ya da terbiye etmek" başlığını taşıyor. Yazarın belirttiğine göre çocuklar ilk eğitimlerini ailede alır; ailede bu görevi üstlenen ise öncelikli olarak annedir. Çünkü babanın ailenin geçimini sağlamak için dışarıda uğraşması gerekmekte; 
dolayısıyla ev ve çocukla ilgili meseleler annenin sorumluluğunda bulunmaktadır. Osmanlı ailelerinin ekonomik durumlarına göre çocuk yetiştirme görevinde sütanneler ve dadıların devreye girdiklerini de unutmamak gerekir.

İkinci bölümün en geniş konuları arasında okullar ve bu okulların kuruluşunu şekillerinden vakıflar bulunmaktadır. Araz'ın çalışmasında mekteplerin kurulması, varlıklarını devam ettirmesi ve gelir kaynakları gibi hususlar hakkında tatmin edici bilgiler yer almakta. Buna karşın mektepteki çocukların durumları, mektebe kaç yaşında başladıkları ve buraya kaç yıl devam ettikleri hakkında net veriler bulunmamaktadır. Mekteplerin yaygın ama zorunlu olmadığı, dolayısıyla çocuğunun işgücünden faydalanmak isteyen ailelerin çocuklarını buraya göndermeye zorlanmadıkları da yazarın altını çizdiği bir başka husustur. Dolayısıyla çocukların mekteplerle ilişkilerinde ailelerin sosyal ve ekonomik düzeylerinin belirleyici olduğu kesin görünmektedir. Nitekim eserde belirtildiği üzere ailevi zorunluluklar, birçok çocuğun mektebe gidememesi, gidenlerin de burada akranlarından daha az zaman geçirmeleri sonucunu doğurmaktaydı.

Yine de mektep çağına gelen çocuklar yetişkinlerin dünyasından kopacak ve akranlarıyla daha fazla vakit geçirdikleri kendi dünyalarını kurmaya başlayacaktır. Tabii ki kız ve erkek çocuklara uygulanan farklı muamele farklı dünyaları yaratacaktır. İlkokulu bitiren kızların bir üst seviyede eğitim alması mümkün değilken erkeklerden şanslı olanları medreselere devam etmektedir. Fakat yazarın belirttiğine göre, "dini bilgileri öğrenme konusunda kız ve erkek çocuklar arasında bir ayırım gözetilmemiştir. Ancak sıra çeşitli hüner ve sanatları öğrenmeye geldiğinde farklılaşma kendini belli etmekteydi. Eğitim aracı olan eserler, genel olarak erkek çocuklar gözetilerek kaleme alınıyordu. Zaman zaman kız çocuklarına hangi hünerlerin kazandırılması gerektiği üzerinde de durulmaktaydı. Erkek çocukların hayatlarını devam ettirebilecekleri bir sanatı olmalı, kızlar ise haya ve iffetle birlikte "eve müteallik sanatlar" öğrenmeliydi.

Peki çocuklar nasıl vakit geçirmekteydi? Araz’ın belirttiğine göre araştırmalar, çocukların insanlık tarihinin her döneminde kendilerine çeşitli eşyalardan oyuncaklar yaptıklarını ortaya koymuştur. Dolayısıyla Osmanlı toplumunda da çocukların kendi oyunlarını ve oyuncaklarını ürettiklerini düşünmek doğaldır. Nitekim Âşsk Paşa'nın Garib-name’sinde geçen haliyle çocuğun tanımına yer veren yazar, "çocuk iyiliği ve kötülügü birbirinden ayıramayan, her anını oynayarak geçirmek isteyen bir varlıktan başka bir şey değildir” demektedir. Fakat eserde, 20. yüzyılın ilk çeyreğinde İstanbul üzerine yazılan bir kitaba atıfla, İstanbullu çok az kadının (anne/sütanne/ dadı) çocukların içindeki oynama arzusunun farkında olduğu yer almaktadır. 
Özellikle "tebenni” (evlat edinme) konusunun ele alındığı ve dönemin sosyo-ekonomik bir tahlilin yapıldığı üçüncü bölümün adı "Yoksulluk ve çocuk emeği” dir. Yazarın belirttiğine göre Osmanlı toplumunda yoksulluk yaygındı ve büyük kentlerde dilencilik yapmak zorunda kalan ya da başka ailelere verilen çocuklar, önemli oranda yoksulluğun bir sonucu olarak ortaya çıkıyordu. Öyle ki, yoksullukla boğuşan aileler bir an önce kızlarını evlendirip evden bir nüfusun eksilmesini umuyordu.

Ailelerin yoksullukla baş etmede umudu olan çocuklar, ailenin geçimine katkıda bulunması için erken yaşlarda çıraklık eğitimine veriliyordu. Çıraklık sürecinin erken başlamasında yoksulluğun yanı sıra elbette yetim ve kimsesiz çocuk olmanın doğurduğu zorunluluklar da yer almaktadır. Bu zorunluluklar sebebiyledir ki, çocuklar mekteplerden alınıp ustaların yanına verilmekteydi. Tabii ki 5-6 yaşındaki çocukların yapılan zanaatin gerekliliklerini yerine getiremeyeceklerinden bahseden yazar, ustaların işlerini daha rahat yapabilmesi için çocukların ayak işlerine baktığını yazmaktadır.

Annesini kaybetmiş, babasının da kendisine bakamayacağı çocukların başka ailelere verilmesi Osmanlı toplumunda "tebenni" yani "besleme" kavramıla karşılanmaktadır. "Tebenni”" nin yoksulluk sonucu ortaya çıkan bir uygulama olduğu düşünülebilir. Fakat eserde belirtildiğine göre tarihçiler, ailenin bir çocuğu neden besleme olarak verdiği sorusuna farklı farklı cevaplar vermektedir. Ancak değerlendirmelerde hayırseverlik ve yardımlaşma niyeti ön planda tutulmaktadır. Nitekim Araz, tebenni uygulamasının, çocuğu veren ve alan aileler arasında bir tür yardımlaşma olarak görüldüğünden bahsetmektedir. Buna göre varlıklı aileler, yoksul ailelerin çocuklarını yanlarına alarak ve büyüterek önemli bir dayanışma sergilemiş ve yardımda bulunmuş oluyorlardı. Ancak tebenni uygulamasında çocukların yaşları ilerledikçe artan bir şekilde ev içi hizmetlerde istihdam edildikleri de problemin bir başka boyutunu göstermesi açısından dikkate değerdir. Nitekim yazar, ailelerinden uzakta olan bu çocukların, aslında kendilerine yabancı olan bir evde cinsel istismara ve baskıya uğradığını gösteren kayıtların varlığından bahsetmektedir.

18. ve 19. yüzyıllarda köle kadın kullanımının önceki dönemlere göre daha az olduğunu belirten kaynaklara Araz, "köle emeği kullanımında yaşanan gerilemenin 18. yüzyılın ikinci yarısıyla birlikte artan bir şekilde tebenni edilen çocukların emeğiyle telafi edilmeye çalışıldığını düşünmek mümkündür” yorumunu yapmaktadır.

Sonuç kısmına gelindiğinde ise, yazar Osmanlıların modernleşme sürecinin çocuklarla ilgili algılarda yol açtığı dönüşümlere karşın, çocukluğun sınırlarını, 
onların fiziksel ve cinsel gelişimlerine paralel olarak tanımlamaya devam ettikleri yorumunu yapmaktadır. Nitekim İslâm hukuk kodu olan Mecelle'de kızların 9, erkeklerin ise 12 yaşında buluğa ermiş oldukları kabul edilmekteydi. Araz bu sınırların, Osmanlıların çocukluktan ne anladıklarının en dikkat çekici yansımalarından biri olup, imparatorluğun sön dönemlerinde de varlığını devam ettirdiğini belirtmiştir

Osmanlı toplumunda çocukların tarihiyle ilgilenmenin bir dönem bazı tarihçiler tarafından "çoluk çocuk" işi olarak görülmesi, Araz'ın tespit ettiği ilginç noktalardan bir başkası. Fakat ne enteresandır ki vaktiyle küçümseyici tavırlara muhatap olan konu bugün, toplumsal tarih araştırmalarında "üst düzey" bir merak konusu olarak yerini almış bulunuyor.

Asiye Kakırman Yıldız

Fatih Ermiş,

\section{A History of Ottoman Economic Thought Devolopment Before the Nine- teenth Century,}

London and New York: Routledge, 226 pp., ISBN 978-0415540063

Son dönemde Osmanlı iktisadi düşünce tarihi konusunda yurt dışında yayınlanan ve etraflı bir çalışmanın ürünü olan kitap, giriş ve sonuç ile birlikte toplam sekiz bölümden oluşmaktadır. Türkiye'deki arşiv ve kütüphaneler başta olmak üzere Almanya ve Viyana'daki kütüphanelerde bulunan kaynakların kullanıldığı ve analitik olarak hazırlanmış bir indekse sahip olan eser, iktisadi düşüncenin temellerini, XIX. yüzyıla kadarki süreçte Osmanlı İmparatorluğu'ndaki durumunu, gelişim ve uygulamalarını anlatan ve bu konunun hangi kaynaklardan çalışılabileceğini gösteren bir araştırmadır.

Yazar, Osmanlıların Doğu ile Batı arasında bir sentez olduğunu, bu nedenle ne Batı Asya, ne de Doğu Avrupa tarihinin Osmanlılar bilinmeden anlaşılamayacağını belirtir. Osmanlıların kendilerinden önceki dönemlere ait hem Batı, hem de Doğu yöneticilerinin tecrübelerinden faydalanarak bir sentez oluşturduğunu, kendilerinin İslâmi bir çerçeve içerisinde hareket etmelerine rağmen, gerektiğinde bu çerçeve dışından etkilere de açık olduklarını vurgular. Osmanlı iktisadi düşüncesinin Moğol, İran, Selçuklu, Bizans, Sufizm ve İslâm düşüncesinin bir 